\title{
Actual Aspects of the Displaced Persons' Workforce Potential Realization
}

\author{
Marta Manukhina ${ }^{1 *}$, Marina Melnik ${ }^{2}$, Alexander Rozmyslov ${ }^{3}$ Inna Tatciy ${ }^{4}$ \\ 1,2,3,4 Volodymyr Dahl East Ukrainian National University, Department of Accounting and Taxation, \\ pr. Central 59-a, 93400, Severodonetsk, Ukraine
}

\begin{abstract}
The article considers certain aspects of realizing the workforce potential of the internally displaced persons. The scientific approaches to the category of the "workforce potential" and the interpretation of the "workforce potential of the worker" are defined. The current state of the workforce potential utilization in the country is analysed, the conditions and possibilities of realizing the potential of the internally displaced persons are described. External and internal factors affecting the internally displaced persons adaptation are considered. By statistical evaluation of displaced persons and measures to solve their social problems, conditions and reasons that impede the full realization of workforce potential are considered. It was determined that the problem of employment and the ability to realize their workforce potential is crucial for the internally displaced persons successful adaptation to a new place. The recommendations to stimulate the employment of the displaced persons and their better adaptation in the places of resettlement were formulated.
\end{abstract}

\section{Introduction}

The world experience shows that the effective development and use of the workforce potential of the population is a decisive condition for the successful implementation of the socioeconomic development strategy of the modern state. According to the World Bank's study of 192 countries, only $16 \%$ of the economic growth in the transitional economies countries are due to the production potential, $20 \%$ - to natural resources, and the remaining $64 \%$ are related to the human and social capital [1].

In this regard, it can be concluded that "the new development opportunities are revealed to those countries whose public improvement can ensure the realization of the workforce and creative potential of their citizens and satisfy their needs as much as possible" [2].

\section{Research Analysis and Problem Statement}

Scientific literature of the recent years shows a marked increase in interest in the problems of efficient use of workforce potential. These problems became the subject of research of such Ukrainian scientists as A. Amosha, S. Bandura, D. Boginia, Ye. Grishnova, A. Kolot,

* Corresponding author: marta.manukhina@gmail.com 
E. Libanova, L. Lisogor, S.Paseka, M. Semykina, L. Shaulska, T. Bilorus and others. Despite the significance of the obtained scientific results, scientists adhere to the point of view that the problems of the workforce potential are still not fully investigated. The complexity of the problem is due to the instability of social and labour relations, a systemic crisis in all the spheres of the country's life, the impact of globalization and other external factors. In modern conditions, such factors include the annexation of the Crimea and the protracted conflict in the south-east of the country, which led to an increase in the number of internally displaced persons from the Crimea, Donetsk and Lugansk regions of Ukraine.

The article aims to analyze the current problems of the implementation of the workforce potential of the internally displaced persons (forced immigrants) in Ukraine.

\section{Research Results}

Note that the interpretation of the category "workforce potential" is still debatable. Despite the fact that there are various approaches in the literature, it is common for many authors to focus on the qualitative characteristics of the workforce potential - health, physical and psychological ability to work, education, qualifications, experience, morality, professionalism, labor, and creative activity. mobility and so on. Many authors (O. Grishnova, M. Semykina, L. Shualska $[3 ; 4 ; 5])$ consider the workforce potential multifaceted, at different economic levels. The authors distinguish the workforce potential of an individual employee, the workforce potential of an enterprise, the workforce potential of a region, a country as a whole with quantitatively inherent qualitative characteristics. Of course, such an integrated approach enriches the theoretical understanding of the workforce potential at the present stage of the development of science, and makes it possible to systematically evaluate the components of the workforce potential. [6].

Developing the authors' existing approaches to the definition of the concept "workforce potential" $[3 ; 4,5,7]$, we propose to interpret the workforce potential of an employee - as a set of physical, mental, moral, educational, motivational capabilities of the individual and his her abilities to work, which are formed, developed throughout life, realized in the process of work, being under the influence of subjective and "objective factors that determine the effectiveness of the workforce efforts and the degree of labour activity of an employee. It is through the development and realization of their workforce potential that each working, capable adult person feels as a full member of the society [8].

The workforce potential of Ukraine, which exists now, in its qualitative parameters does not correspond to the strategic objectives of economic and social development. Workforce potential is reduced quantitatively, deteriorating in its qualitative characteristics. These trends are explained by a combination of reasons - a grave demographic crisis, the lack of effective structural reforms in the economy, and ineffective socio-economic policies. As a result, there is a low birth rate, premature mortality, high morbidity, limited access of the population to quality medical services and quality education; ineffective employment, and low social standards. As a result of the imbalance in the demand and supply of the workforce in the labor market there is forced labor migration abroad, an outflow of the most active and educated young people.

In addition, today's realities have revealed that the society is not ready to solve new problems. First of all, it concerns the imperfection of the socio-economic mechanisms of workforce potential realization for the internally displaced persons in the context of the military conflict in the east of Ukraine. The acuteness of the problem dictates the need for a scientific study of the depth of the problems in the workforce potential realization of the internally displaced persons and finding ways to solve them. The Ukrainian society today find itself unprepared for the situation with the emergence of a large number of internally displaced persons inside the country and unable to coordinate actions to ensure the conditions for their workforce potential realization. The effectiveness of the state policy in solving the problems of the internally 
displaced persons is insufficient. Some achievements of legislative and regulatory support for internally displaced persons do not provide the expected results due to the low quality of the national and regional governance, inconsistency of the legislation and the possibilities for its implementation.

With regard to the current situation, we consider it is necessary to develop a clear program of measures for the effective use and development of the internally displaced persons workforce potential.

According to the UN Guiding Principles on Internal Displacement, internally displaced persons are "persons or groups of persons who have been forced or obliged to flee or to leave their homes or places of habitual residence, in particular as a result of or in order to avoid the effects of armed conflict, situations of generalized violence, violations of human rights or natural or human-made disasters, and who have not crossed an internationally recognized border" [9].

In international law, the term "internally displaced persons" is a category of forced migration, used along with the concepts of "refugees" and "displaced persons". As a rule, in case of forced migration, all the main indicators of the quality of life deteriorate: the well-being, living conditions, social status.

In Ukraine, the main reasons for such a move were the annexation of Crimea, the escalation of the military conflict in the Lugansk and Donetsk regions, the danger to the life and health of the population, civilian casualties, and the destruction of buildings. According to the United Nations Office for the Coordination of Humanitarian Affairs and the Ministry of Social Policy of Ukraine, as of the end of 2018, the number of internally displaced persons from Donbass and Crimea was 1,515,158 people. General information on displaced persons is presented in table 1 .

Table 1. Information on the displaced persons as of the end of 2018 [13]

\begin{tabular}{|c|c|c|c|}
\hline Regions of Ukraine & $\begin{array}{c}\text { Number of the displaced } \\
\text { from Donbass and } \\
\text { Crimea (persons) }\end{array}$ & $\begin{array}{c}\% \text { of the total number } \\
\text { of displaced persons }\end{array}$ & $\begin{array}{c}\text { \% of the } \\
\text { Population of the } \\
\text { region of arrival }\end{array}$ \\
\hline Total & $1,515,158$ & 100.0 & - \\
\hline Vinnytsya & 11,414 & 0.75 & 0.64 \\
\hline Volyn & 2,949 & 0.19 & 0.28 \\
\hline Dnipropetrovsk & 74,342 & 4.9 & 2.09 \\
\hline Donetsk & 552,116 & 36.43 & 19.05 \\
\hline Zhytomyr & 7,242 & 0.48 & 0.64 \\
\hline Zakarpattia & 3,662 & 0.24 & 0.22 \\
\hline Zaporizhzhia & 55,896 & 3.69 & 4.26 \\
\hline Ivano-Frankivsk & 3,587 & 0.23 & 0.24 \\
\hline Kyiv & 65,590 & 4.33 & 1.96 \\
\hline Kyiv (city) & 164,813 & 10.88 & 2.7 \\
\hline Kirovograd & 6,628 & 0.44 & 0.83 \\
\hline Luhansk & 129,500 & 19.47 & 19.32 \\
\hline Lviv & 10,947 & 0.72 & 0.32 \\
\hline Mykolaiv & 8,556 & 0.56 & 0.7 \\
\hline Odesa & 41,436 & 2.73 & 0.92 \\
\hline Poltava & 25,413 & 1.68 & 1.7 \\
\hline Rivne & 3,249 & 0.21 & 0.27 \\
\hline Sumy & 11,248 & 0.74 & 1.15 \\
\hline Ternopil & 2,121 & 0.14 & 0.22 \\
\hline Kharkiv & 126,701 & 8.36 & 5.04 \\
\hline Kherson & 14,199 & 0.94 & 0.95 \\
\hline Khmelnytsky & 6,339 & 0.42 & 0.5 \\
\hline Cherkasy & 11,344 & 0.75 & 0.9 \\
\hline Chernivtsi & 2,449 & 0.16 & 0.24 \\
\hline Chernihiv & 8,550 & 0.56 & 0.72 \\
\hline & & & \\
\hline & & & \\
\hline & & & \\
\hline & & & \\
\hline & & & \\
\hline & & & \\
\hline & & & \\
\hline
\end{tabular}


According to the table above, it can be concluded that most migrants are concentrated in the Donetsk, Kharkiv, Lugansk regions, Kyiv, Zaporizhzhia and Dnipropetrovsk regions, 53.3\% of migrants are located in the first three regions, and $19.5 \%$ in the last three, that is, six regions received $72.8 \%$ of all IDPs.

Forced migrants face a whole range of problems, including:

housing problems (accommodation)

employment problems;

medical care problems;

problems with the provision of pre-school and school education services;

psychological problems;

lack of social protection.

A number of urgent issues regarding the registration and livelihoods of internally displaced persons and their family members in the new living conditions are considered by the Law of Ukraine "On Ensuring the Rights and Freedoms of Internally Displaced Persons" dated October 20, 2014 No. 1706- VII. However, it is impossible to solve the whole set of diverse problem situations in life support, employment, social security with one law. It is necessary to change the state and regional policies regarding migrants, to search for new mechanisms to stimulate the employment of internally displaced persons.

It should be noted that the resettlement of the internally displaced persons requires huge expenses, and therefore, together with the unresolved problems of the livelihood of a significant part of Ukrainian citizens already living in this territory, forced migration can aggravate the already tense situation in the labour market, housing, and exacerbate inter-ethnic conflicts. On the other hand, an increase in the able-bodied population could create favourable opportunities for improving the demographic situation, perhaps only with the implementation of an effective state policy in terms of preparation at all levels for receiving, accommodating and settling migrants [11].

Due to its social, economic and psychological consequences, forced relocation is a real life catastrophe for most adults, especially when it happens in a limited time interval, which makes it impossible at least to some extent to morally, financially, physically prepare for a change of residence. In the conditions of war, the overwhelming majority of immigrants found themselves in a situation of difficult life choices - to move, find a job and get used to living in a new place or to consider leave as temporal and be ready to return.

There is an urgent need to quickly adapt to new living conditions, and the success of such adaptation depends on external factors, relating to the resettlement region, and internal, characterizing the most forced migrants, their particular nature, mentality, readiness for any job, change of profession, retraining.

The external factors include such indicators as the density and demographic structure of the population of the region, the development of the economy, the need for workforce; availability of free housing; the development of social and industrial infrastructure; resource potential; climate and so on.

Internal factors include gender, age, education, specialty, qualification; marital status, level of material security, character trait.

The problem of employment and the ability to realize their workforce potential is, in fact, important for the successful adaptation of internally displaced persons to a new place. Having left as a result of involuntary resettlement without housing and a significant part of the acquired property, people retain practically their only capital - knowledge, skills, labor skills, certain abilities to display mobility, retraining, communications.

However, the issue of employment is very problematic due to the general economic crisis in the country, the ratio of prices in the housing and labor markets, forcing people to choose not the place where there is a job, but where they can find affordable housing. As long as such a 
discrepancy between the cost of housing and the existing level of salary will persist, there can be no rational use of the internally displaced persons workforce potential. [12].

In addition, it is necessary to note the internally displaced persons various abilities to adapt: unequal psychological readiness to find a job, retraining, get a new specialty. This is influenced by age, profession, level of education, skill level, and the like.

\section{Conclusion}

Considering the problems of comprehensive realization of the internally displaced persons' workforce potential, a number of new mechanisms to stimulate their employment in resettlement regions can be identified. The main ones include the following:

1. Providing employers who employ internally displaced persons with compensation for their wages.

2. Reimbursement to the employer of the costs for retraining and advanced training of employed forced migrant.

3. Expanded coverage of the internally displaced persons with vocational training, retraining and advanced training (by redistributing the licensed students recruitment for training, retraining and advanced training).

4. Expansion of the international cooperation (implementation of joint projects with international organizations that are aimed at developing employment).

5. Creation of new jobs with the help of technology parks and business incubators.

Thus, the internally displaced persons adaptation to the new conditions, creation of the possibility for the full realization of their workforce potential acts as a complex and multi-level process, affecting the legal, socio-economic, socio-cultural, socio-psychological aspects. A systematic approach to solving these complex tasks requires the state to develop a well-thought out concept of the state migration policy.

\section{References}

1. Human Development Report, 1994.-New York, Oxford: Oxford University Press, (1994).

2. Bilorus T. Visnyk Kyivskogo nacionalnogo universytetu imeni Tarasa Shevchenka. Seriya "Ekonomika", 137, 42-45 (2012).

3. Grishnova O. A. Lyudskiy rozvytok: Navch. Posib. - K. : KNEU, 308 (2006).

4. Semykina M.V. Naukovi praci Kirovogradskogo nacionalnogo texnichnogo universytetu. Ekonomichni nauky. 16(1), 3-10 (2009).

5. Shaulska L. V. Strategiya rozvytku trudovogo potencialu Ukrayiny: monografiya. Donetsk: NAN Ukrayiny, In-t ekonomiky prom-ti, 502 (2005).

6. Pasyeka S. R. Socialno-trudoviy potencial regionu: teoriya i praktyka rozvytku: Monografiya . Cherkasy: "IntroligaTOR", 608 (2012).

7. Ratnikov D.G. Pidvy shhennya konkurentospromozhnosti trudovogo potencialu naymanykh pracivnykiv $v$ Ukrayini $v$ umovax globalizaciyi. In-t demografiyi ta socz.doslidzh. NAN Ukrayiny.- K., (2010).

8. Drozdova E. M. Dy`skussy`ya. 5, 17-22 (2012).

9. Ofy`cy`al`nij sajt UVBK OON: [Elektronnuj resurs].URL: http://unhcr.org.ua/en/.

10. Libanova E.M. Vymushene pereselennya z Donbasu: masshtaby ta vyklyky dlya Ukrayiny. Vnutrishno peremishheni osoby v Ukrayini: realiyi ta mozhlyvosti /Materialy Mizhnarodnoyi naukovo-praktychnoyi konferenciyi (27 lyutogo 2015 r. m Kyiv).Available at: http://ief.org.ua/wp-content/uploads/2015/02/Libanova2015.pdf. 
11. Semykina M.V., Pustovit M.V. // Formuvannya ry`nkovoyi ekonomiky: zb. nauk. pr. Specz. vyp. Pracya v XXI stolittya: novitni tendenciyi, socialnyj vymir, innovacijnyj rozvytok : u 2 t. - .2. - K.: KNEU, 2012. - S. 370 -379.

12. Pasyeka S.R., Semykina M.V., Fedunets A.D. Model ocinky socialno-trudovogo potencialu regionu v konteksti obgruntuvannya strategiyi modernizaciyi ekonomiky na zasadax innovacijnogo rozvytku / Innovacijna model rozvytku: tendenciyi ta perspektyvy ekonomichnoyi transformaciyi [Kolektyvna monografiya]: Uman, PP Zhovtyj O.O., 2014 r. - S. 202- 213.

13. www.kmu.gov.ua/ua/news/pyat-rokiv-peremishchennya-problemi-ta-uspihi-integraciyiu-gromadi 